\title{
IMPROVING STUDENTS' SPEAKING SKILL USING DIGITAL PHOTOS THROUGH ONLINE LEARNING
}

\author{
Fasaaro Hulu \\ Universitas Karimun (UK), Kepri, Indonesia \\ fashulu@gmail.com
}

\begin{abstract}
This research aimed at improving and developing the students' speaking skill by using digital photos online. This research used zoom meeting aplication in online laerning toward the third grade of SMK Yos Anugrah Batam. The methode applied was a qualitatif research approach by descrining a picture, telling daily activities and telling experience. The research works conducted for three times in order to find out the improvement and the result of the participants. Each research works end, the partcipants were given test and questionaire to collect the real data by online. Data collected were analysed by scoring the students' achievement for each activity based on the speaking ability criterion namely unfair, fair, good, very good and exellent. After the data scored through the test addressed to the students, researcher classified and grouped the data, organized and compared the data source, analyse the data, display and expalin the data in text according to the criterion speaking abilty. The result of this research was that the students' speaking skill was improved and developed shown from the result.
\end{abstract}

Keywords: Digital Photo Online, Improving and Developing, Students' Speaking Skill

\section{INTRODUCTION}

English is one of the languages which are used internationally by most people to exchange information in various countries in the world including in schools and universities. English is a subject which is taught at school and universities. In term of teaching English in the class, each students should show the motivation and ability in English. The ability of the students needed are in undestanding using of correct grammar, vocabulary and pronounciation. Through mastering these three skills, the students get fluency in speaking. Speaking is an act to say words with voices as telling a story, experince, speech, dialogue, discussion, sharing and debating. In telling a story, it seems so difficult to speak it as faced by the students at the school. In the time of asking the story of each student in 
the class, they ask to speak in their Ical language or formal language but not in English, they ask extra time to prepare the story. When they come to their turns, they just speak about one to two minutes. The learners faced problem in speaking, they do not know what the correct words used, the words pronounciation are some incorrect ways, the sentences are unstrustures.

In speaking, vocabulary is the most basic material to build a smooth conversation but difficult for some students to arrange the words, to use the words and speak with the right words according to time usage as in using verbs which has several forms in different time usage as in I have "garden flowers." The words "garden flowers" should be "flowers garden." The student did not understand the wya where to should be put the words but not because of they do not master the vocabulary. In speaking, it is not only to know the vocabulary meaning but also to understand to place the word in a sentence whey they speak.

Student got problem in saying the word, apologize /apologiz/, it should be /ə'ppl.ə.dzaiz/. the students got difficult to say the word correctly. Beside the word "count" spoke as /kont/. The word "count" should be pronounced as /karnt/ . Doing mistake in saying words can make the meaning different from its real pronounciation and it might have different meaning. Every student should understand the correct pronounciation for each word whenthey speak.
I " $g o$ " to visit my grand father last month and he "write" a sentence in English. The word " $g o$ " in the first sentense should be "went" and the word "write" in the second sentence is should be "writes.". The student faces pfoblem in using verbs in different time, such as in the present simple tense. every sentence must apply the correct tenses both in speaking or in writing. If a sentence uses uncorret grammar called as ungrammaticall sentence. So the sentense is not perfect without supporting good grammar the using of part of speech.

This research was to explain the image-based activity method is improves the students' speaking skill through online learning and elaborate the image-based activities method improves the students' speaking skill. In this research, the researcher includes the previous researchers that had been ever done related to the speaking. First, In Pakula, Hein, (2019), said, "to be able to communicate fluently in a foreign language, can be taught based on 1) how speaking is learned and 2) how speaking proficiency is defined. Specifically, 1) How do learning theories translate into teaching speaking at classroom level? and 2) What is the significance of the current understanding of language proficiency as reflected in the models of communicative competence and the Common European Framework (Council of Europe, 2001) and its Companion Volume with New Descriptors (Council of Europe, 2018) to the teaching of speaking in formal 
foreign language contexts? The pedagogical implications concern the teaching of fluency and formulaic sequences, the teaching of spoken grammar, the teaching of linguistic, sociolinguistic and pragmatic competences.

In Mounika, K. \& Thamarana, S., (2018), deals with certain prospects and possibilities involve in teaching speaking onlinerelated aspects. Since, speaking skill is much required for all students regardless of their courses and aspirations, the importance of speaking skill as well as its most essential subskills have been presented in the outset. Most importantly, the role of technology in teaching speaking skills including supra segmental features such as stress, rhythm and intonation. Further, the presentation of various online resources including applications as well as various media like audio, video, text, animation and graphics. The resources categorised as speaking practices/activities, voice recording, pronunciation practice, online presentations, video chats, and mobile apps including Voki, Vocaroo, AudioPal and others.

\section{LITERATURE REVIEW}

\subsection{Speaking}

Speaking is the real tool of language to share and communicate the ideas for everyone, Tahir, S, Z, B, \& Hanapi,(2017, p.2 ). Speaking is the basic instrument acts to construct meaning that involves producing, receiving and processing the information interactive process (Finocchiaro in Sukrianto, 2005, p.
22; Burn \& Joyce, 1997, p. 63). In Brown (2004, pp. 331-332) wrote the teaching principles for speaking skill

1. The objective of learning focuses on fluency and accuracy

2. Motivating the students by giving the fundamentally techniques

3. True language used in the right contexts

4. Giving the right feedback and corrections

5. Capitalizing on the natural link between speaking and listening

6. Providing the opportunities for students to share in process of learning

7. Inspiring the students to encrese the strategy and style in speaking

2.2. Online learning (Jones, Cery, 2018)

1. Make sure at the starting of the course is everything goes smoothly

2. Do recordings; record online classes to help teachers and also students can watch, listen and go back to the same interaction. This is a great actiivities to gain feedback, strenghtening and correction.

3. Focus to support on tasks

4. Maintain the participations and engagement

5. Providing everyone has opportutnity to share and speak by not worrying about correcting some errors and grading the performance

6. Recording used for evaluating output and feedback. 
7. Make sure all the audio is functioning and video works

8. Participants are able to navigate and follow the classroom

9. Participants can use the chat box

10. Participants are able to raise the hands

11. Participants are familiar to use live text messaging and video chats

\subsection{Teaching speaking online}

1. Starting by eazy brainstorming activities, perhaps the students place answers in chat box

2. On the screen, show to the partcipants using shared whiteboard

3. Game in quick word is appropriate too, such as finding a word in the word square game and ask the participants to compose sentences or give meanings for the words

4. Providing participants thinking moment first or try to offer the answer model before suggesting to answer the questions.

5. Make breakout rooms to discuss questions

6. Do the activities of imagebased, share some photos. And encourage each student to question about the photos. Then ask the students to share photos of their own, let them talk about the photos.

7. Share the a movie poster, a book covers, a famous city image and also landmark, to stimulate conversations
8. Each of the student makes a recorded presentation and share it inthe discussion forum

2.4. Preparation or planning speaking practice online (Jones, Cery, 2018)

1. Leading conversation. Such as having a clear protocol to take turn by using chat box or using hands-up icon)

2. Give tasks and provide a chance to speak and ensure that but do not repeating the same thing.

3. Give task to keep the listeners tuned in bay having a circular story-telling and pay attention in as they will have next turn

4. Calling on someone differently to summarise what had been what had been spoken

5. Variety of balances. Provide more than one tasks simply for a lesson

6. Supporting screen for all lesson stages. Provide a welcoming screen at the beginning and a thank at the end meeting.

7. Provide an image, an icon, an illustration and a table to support the task and instructions

8. Prepare everything before handing and monitor the conversations

\subsection{Picture cued story telling task}

Accoding to Brown (2014:180) stated the common techniques used in oral production is using a visual picture, a photograph, a diagram and a chart. Pictures or a pictures series can stimulus for longer conversation, story or description. 
Vol. 3 No. 2

December 2021

e- ISSN 2685 - 0559

p- ISSN 2684 - 673X

And, the visual picture or photograph provide describtion for the test-takers using Picture cued requires. Picture is a very simple design to get a word, a phrase or sentence, wide elaboration, composing a series incident or a story

\subsection{Speaking Assesment \\ Oral proficiency scoring in vocabulary, pronunciation, grammar, fluency, comprehension in Brown (2004:172)}

\begin{tabular}{|c|c|}
\hline Vocab & \\
\hline \multirow[t]{6}{*}{ Score } & Explanation \\
\hline & Inadequate to express anything and speaking words but the most elementary \\
\hline & having speaking words sufficient to simply express something \\
\hline & having sufficient words to involve effectively to use the language \\
\hline & participate and understand in conversations in range \\
\hline & $\begin{array}{l}\text { native speakers is fully accept the spoken in all features and levels; using } \\
\text { idioms and, colloquialisms and references in pertinent cultural. Experience } \\
\text { and circumlocution in sepaking with exact words in high degree. Informal and } \\
\text { formal talks on professional needs, practical, social, and any topics. Rarely } \\
\text { groping words and having broadly vocabulary. }\end{array}$ \\
\hline \multicolumn{2}{|c|}{ Pronunciation } \\
\hline & errors to pronoun words frequently but the native speakers can understand \\
\hline & Clear enough in accent though frequently quite faulty \\
\hline & $\begin{array}{l}\text { never interfere errors with knowing the meaning and rarely intereupt the } \\
\text { native speaker }\end{array}$ \\
\hline & errors in word pronunciation is quite unusual \\
\hline & $\begin{array}{l}\text { fully understood and equivalent by the native speakers. Eazy to understand } \\
\text { the foreign accent used to agree with a foreigner attempting to use and speak } \\
\text { the language }\end{array}$ \\
\hline \multicolumn{2}{|r|}{ ( } \\
\hline & Frequently errors in grammar, but native speaker understood the speaker \\
\hline & quite accurately and usually able to hand the elementary constructions \\
\hline & Good controll grammar and able to speak the language \\
\hline & accurately to speak on the language for all levels \\
\hline & $\begin{array}{l}\text { equivalent to an educated native speaker. nonformal conversations on a } \\
\text { professional topic practical and social. Pertinent to needs of professional. } \\
\text { Rarely errors in using grammar. grammar accuracy is sufficient to involve } \\
\text { effectively in formal context and confident to use grammar to understand } \\
\text { with foreigners to speak the language }\end{array}$ \\
\hline \multicolumn{2}{|c|}{ Fluency } \\
\hline & fluency description is no specific. May be implied into four languages areas \\
\hline & $\begin{array}{l}\text { Fluently to hand with confidence but not fluency with facility most social at } \\
\text { particular time }\end{array}$ \\
\hline & Fluently to discuss the competence in particular interest with reasonable ease \\
\hline & fluently to use the language on all levels normally pertinent to professional \\
\hline & $\begin{array}{l}\text { complete fluency to use language and fully accepted by fluency in a high } \\
\text { degree, an educated native speaker. Information of autobiographical and } \\
\text { family. Able to participate in any conversation }\end{array}$ \\
\hline
\end{tabular}




\section{RESEARCH METHODOLOGY}

Research methodology is a way to systematically solve the research problem. In it we study the various steps that are generally adopted by a researcher in studying his research problem along with the logic behind them. It is necessary for the researcher to know not only the research methods/techniques but also the methodology, (Kothari, 2004 : 4).

In this research, the writer applies the method of qualitative research to describe the speaking mistakes throuh Englishdialoques in the front of the class. "Qualitative research is interpretative research, with the inquirer typically involved in a sustained and intensive experience with participants. This introduces a range of strategic, ethical, and personal issues into the qualitative research process. With these concerns in mind, inquirers explicitly identify reflexively their biases, values, and personal background, such as gender, history, culture and socioeconomic status, that may shape their interpretations formed during a study, (Creswell, 2009 : 165)

This research conducts at SMK Yos Anugrah Batam to improve the students speaking skill through online teaching. Method used to gather reserch data is questioner given to the students. The method applied are including the data collecting, analyzing the data, result displays and conclusion. This research conducted in SMK Yos Anugrah Batam at the 3rd grade. SMK Yos Anugrah Batam is one of the privat schools in Batam which is based in Bengkong. The population of this reseach are all the grade 3 of the students of Yos Anugrah Batam. Englishis one of the curriculumn part which is taught at school for almost three years. The researcher wanted to describe whether the students improve their speaking in Englishbased digital photos in online learning.

Observation and questioners carried out to find out the data. Close questioners are addressed to the students to get their real data in texts. In this research, the questionnaires consisted of fifteen questions numbers related in improving speaking skills.

Before applying the research, researcherconducted an online class to see the real condition and to complete the research data. There are some steps applied by the researcherto collect the data. In the end of the meeting, the participants are given test

1. The researcher conducted the first online teaching by using pictures

2. The researcher ased the students tell their daily activities

3. The researcher asked the students to tell their experiences

After collecting the data, "those have to be processed and analysed in accordance with the outline laid down for the purpose at the time of developing the research plan. Data analysis in qualitative research, (Creswell, $2007:$ 1720. The type of data analyzed may be numeric information gathered on scales of 
instruments or text information recording and reporting the voice of the participants in Creswell (2009: 32). in this data analysis, writers organize the data and veryfiying the data as below

1. Researcher organized and prepare the data to analyse.
2. Researcher read through all the data collected

3. Researcher began detailed analysis with a coding process.

4. Researcher organized the data into table, segments of text and bring the meaning to information

Table 1. The explanation for the aspects of speaking ability, scores and criterion

\begin{tabular}{|c|c|c|}
\hline Scores & Criterion & Explanation \\
\hline 90-100 & excellent & $\begin{array}{l}\text { Exellent to use of English. Quite clear oral production. } \\
\text { Experiences little or no difficulty in understanding. Almost } \\
\text { no errors of phonology, grammar or lexis }\end{array}$ \\
\hline $80-89$ & Very good & $\begin{array}{l}\text { Satisfactory verbal communication. Limited number of } \\
\text { errors of grammar, lexis or pronunciation. Occasional self- } \\
\text { corrections. Little } \\
\text { difficulty in understanding. }\end{array}$ \\
\hline 70-79 & Good & $\begin{array}{l}\text { verbal communication usually fairly satisfactory. Repetition } \\
\text { and } \\
\text { rephrasing sometimes necessary. Experiences some } \\
\text { difficulties in } \\
\text { communicating. Some errors of phonology grammar and } \\
\text { lexis }\end{array}$ \\
\hline $60-69$ & Fair & $\begin{array}{l}\text { Understanding very limited, although communication in } \\
\text { everyday topics is possible. Many errors of phonology } \\
\text { grammar and lexis } \\
\text { Unsatisfactory }\end{array}$ \\
\hline $\begin{array}{l}\text { Fewer } \\
-59\end{array}$ & Unsatisfactory & $\begin{array}{l}\text { Extrem difficulty in communication in any subeject. Failure } \\
\text { to understand adequately and to make him/herself } \\
\text { understand }\end{array}$ \\
\hline
\end{tabular}

After collecting all the data from students' individual scores through the test, scoring formula applied as adapted from brown (2004).

\section{FINDING AND DISCUSSION}

In this chapter, research finding and result of the test explain according to four speaking aspects are vocabulary, pronunciation for each word, the use of grammar to compose

$$
\begin{aligned}
& S A=\frac{V+P+G+F}{4} \\
& S A=\text { Speaking ability score } \\
& V=\text { Vocabulary score } \\
& P=\text { Pronunciation score } \\
& G=\text { Grammar score } \\
& F=\text { Fluency score }
\end{aligned}
$$

correct sentences and fluncey in conversation. The students' speaking performances are devided into five criterion; unsatisfactory, fair, good, very good and excellent.

Table 2. Description of speaking aspects ability for test 1

\begin{tabular}{lllllll}
\hline No. & Participants & Voc. & Pro. & Gram. & Flue. & Score \\
\hline $\mathbf{1}$ & Students 1 & 66 & 64 & 62 & 61 & 63,25 \\
\hline
\end{tabular}




\begin{tabular}{lllllll}
\hline $\mathbf{1}$ & Students 2 & 71 & 65 & 61 & 62 & 73,75 \\
$\mathbf{1}$ & Students 3 & 64 & 60 & 61 & 63 & 62 \\
$\mathbf{1}$ & Students 4 & 60 & 62 & 56 & 61 & 59,75 \\
$\mathbf{2}$ & Students 5 & 73 & 74 & 71 & 65 & 70,75 \\
$\mathbf{2}$ & Students 6 & 74 & 76 & 73 & 70 & 73,25 \\
$\mathbf{2}$ & Students 7 & 75 & 77 & 76 & 73 & 75,25 \\
$\mathbf{2}$ & Students 8 & 78 & 75 & 70 & 76 & 74,75 \\
& Total & 561 & 553 & 530 & 531 & 543,75 \\
\hline
\end{tabular}

From the table above, it shows the students 1 to 3 have the similar capability in speaking. The capability is categorized in a fair speaking category with the score of 60 to 70 . The students ability in speaking are very limited and a lot error in using grammar, pronunciation and vocabulary. As seen in student 1 , got score 66 in vocabulary, 64 for pronunciation, 62 in grammar and the fluency score is 61 .

The students 5 to 8 are categorized in a good criteria of speaking skill as in student 6 , got good criteria score in mastering vocabulary (74), pronunciation (76), grammar (73) and fluency (70). The speaking range criteria among 70 to 79 are categorized in a good capability in speaking. During the conversation time and test, the students usually communicate quite fairly satisfactory and repetition somoetimes but it shows that some errors found in using grammar and vocabulary.

Table 3. Description of speaking aspects ability for test 2

The second test of speaking skill ability shows the scores and the capability of students related to vocabulary, pronunciation, grammar and fluency shows in the following table

\begin{tabular}{|c|c|c|c|c|c|c|}
\hline No. & $\begin{array}{l}\text { Participa } \\
\text { nts }\end{array}$ & $\begin{array}{l}\text { Vo } \\
\text { c. }\end{array}$ & $\begin{array}{l}\mathrm{Pr} \\
\text { o. }\end{array}$ & $\begin{array}{l}\text { Gra } \\
\mathrm{m} .\end{array}$ & $\begin{array}{l}\text { Flu } \\
\text { e. }\end{array}$ & $\begin{array}{l}\text { Sco } \\
\text { re }\end{array}$ \\
\hline 1 & $\begin{array}{l}\text { Students } \\
1\end{array}$ & 68 & 65 & 64 & 67 & 66 \\
\hline 1 & $\begin{array}{l}\text { Students } \\
2\end{array}$ & 65 & 67 & 63 & 66 & $\begin{array}{l}65,2 \\
5\end{array}$ \\
\hline $\begin{array}{l}1, \\
2\end{array}$ & $\begin{array}{l}\text { Students } \\
3\end{array}$ & 71 & 74 & 68 & 66 & $\begin{array}{l}69,7 \\
5\end{array}$ \\
\hline $\begin{array}{l}1, \\
2\end{array}$ & $\begin{array}{l}\text { Students } \\
4\end{array}$ & 77 & 79 & 78 & 76 & 77,5 \\
\hline $\begin{array}{l}1, \\
2\end{array}$ & $\begin{array}{l}\text { Students } \\
5\end{array}$ & 76 & 71 & 70 & 68 & $\begin{array}{l}71,2 \\
5\end{array}$ \\
\hline 2 & $\begin{array}{l}\text { Students } \\
6\end{array}$ & 78 & 78 & 75 & 77 & 77 \\
\hline 2 & $\begin{array}{l}\text { Students } \\
7\end{array}$ & 76 & 78 & 77 & 70 & $\begin{array}{l}75,2 \\
5\end{array}$ \\
\hline $\begin{array}{l}2, \\
3\end{array}$ & $\begin{array}{l}\text { Students } \\
8\end{array}$ & 81 & 78 & 76 & 79 & 78,5 \\
\hline & Total & $\begin{array}{l}59 \\
2\end{array}$ & $\begin{array}{l}59 \\
0\end{array}$ & 571 & 569 & $\begin{array}{l}580, \\
5\end{array}$ \\
\hline
\end{tabular}

According to the data from the table, it displays three categories and mix of sepaking skill ability are fair, good and very good. The fair category stated in student 1 and student 2 with the score range are 60 to 70 showed the understanding very limited during the communication related to the topic and found many errors in phonology, grammar and vocabulary. Student 3, 4 and 5 are classified as a mix category are fair category and good category as in student 3 , got 71 score in vocabulary and 74 score in pronunciation, categorized in a good capability both voc.and pro., while in grammar got 64 scaore and 67 in fluency, categorized in good capability in 
both gram.and fluency. During the test, the students did repetition and rephrasing sometimes

The students 6 and 7 shows the performance in a good category in speaking skill during the test as seen in the score of student 6 in vocabulary (78), pronunciation (78), grammar (75) and fluency (77). Both the students are is able to communicate fairly satisfactory and did some errors in grammar and vocabulary during the test

The student 8 is classified in mix categories from speaking aspects voc., pro., gram., and flue., very good and good category. The very good category shows in mastering vocabulary with score 81 . During the test did occasional self-corrections and little difficulty in understanding vocabulary while in pronunciation (78), grammar (76) and fluency (79) categorized in a good category and faced some errors in grammar and using vocabulary

Table 4. Description of speaking aspects ability for test 3

The third test of speaking skill ability displays the capability and the score of students undertanding in using vocabulary, pronunciation, grammar and fluency as expained in the table below

\begin{tabular}{lllllll}
\hline No. & $\begin{array}{l}\text { Particip } \\
\text { ants }\end{array}$ & $\begin{array}{l}\text { Vo } \\
\text { c. }\end{array}$ & $\begin{array}{l}\text { Pr } \\
\text { o. }\end{array}$ & $\begin{array}{l}\text { Gra } \\
\text { m. }\end{array}$ & $\begin{array}{l}\text { Flu } \\
\text { e. }\end{array}$ & $\begin{array}{l}\text { Scor } \\
\text { e }\end{array}$ \\
\hline $\mathbf{2}$ & $\begin{array}{l}\text { Student } \\
\text { s 1 }\end{array}$ & 78 & 79 & 76 & 75 & 77 \\
$\mathbf{2}$ & $\begin{array}{l}\text { Student } \\
\text { s 2 }\end{array}$ & 75 & 71 & 74 & 76 & 74 \\
$\mathbf{2}$ & $\begin{array}{l}\text { Student } \\
\text { s 3 }\end{array}$ & 77 & 75 & 72 & 76 & 75 \\
$\mathbf{2}$ & Student & 83 & 84 & 79 & 81 & 81,7 \\
$\mathbf{3}$ & s 4 & & & & & 5 \\
$\mathbf{2 ,}$ & Student & 79 & 81 & 79 & 78 & 79,2 \\
\hline
\end{tabular}

\begin{tabular}{lllllll}
\hline $\mathbf{3}$ & s 5 & & & & & 5 \\
$\mathbf{2}$ & Student & 79 & 81 & 79 & 78 & 79,2 \\
$\mathbf{3}$ & s 6 & & & & & 5 \\
$\mathbf{3}$ & $\begin{array}{l}\text { Student } \\
\text { s 7 }\end{array}$ & 80 & 81 & 80 & 82 & $\begin{array}{l}81,2 \\
5\end{array}$ \\
$\mathbf{3}$ & $\begin{array}{l}\text { Student } \\
\text { s 8 }\end{array}$ & 85 & 84 & 82 & 81 & 83 \\
& & & & & \\
& Total & 63 & 63 & 621 & 627 & 630 \\
& 6 & 6 & & & \\
\hline
\end{tabular}

Base on the data from the table, students ability in speaking are grouped in three different categorized, the sudents 1,2 and 3 categorized in a good capabilty in speaking, Students 4,5 and 6 are mix categories are a good and very good in speaking and students 7 and 8 categorized in a very good in speaking.

Students 1, 2 and 3 use verbal communication and usually fairly satisfactory, occasionally did repetition and rephrasing, faced some obstacles in describing the pictures and some errors used in grammar and vocabulary as seen in student 1 , got score in vocabulary (78), pronunciation (79), grammar (76) and fluency (75).

Students 4, 5 and 6 are mix categories are a good and very good in speaking as in student 5 , got score 81 in pronunciation is included in a very good category with occasional self-corrections and faced little difficulty in understanding in pronunciation. While in vocabulary (79), grammar (79) and fluency (78) is good categorized in the three of speaking aspects, the student spoke verbal communication, made repetition, rephrasing sometimes, faced some barriers in explaining and giving idea through the picture 
and some mistakes in using vocabulary and grammar.

Students 7 and 8 categorized in a very good in speaking with 85 score in vocabulary, 84 score in pronunciation, 82 score in grammar and 81 score in fluency. Both the students are able to expresses satisfactory verbal communication, little number of of using grammar, vocabulary, pronunciation, sometimes did self-corrections, little difficulty in understanding the talks and give some elaboration about the topic.

Table 5. Description of speaking aspects ability for test 4

The fourth test of speaking skill ability shows in data below. The students capability and the score describe in table related to the use of vocabulary, pronunciation, grammar and fluency

\begin{tabular}{|c|c|c|c|c|c|c|}
\hline No. & $\begin{array}{l}\text { Participa } \\
\text { nts }\end{array}$ & $\begin{array}{l}\text { Vo } \\
\text { c. }\end{array}$ & $\begin{array}{l}\mathrm{Pr} \\
\text { o. }\end{array}$ & $\begin{array}{l}\text { Gra } \\
\text { m. }\end{array}$ & $\begin{array}{l}\text { Flu } \\
\text { e. }\end{array}$ & $\begin{array}{l}\text { Scor } \\
\text { e }\end{array}$ \\
\hline $\begin{array}{l}2, \\
3\end{array}$ & $\begin{array}{l}\text { Students } \\
1\end{array}$ & 80 & 82 & 79 & 78 & $\begin{array}{l}79,7 \\
5\end{array}$ \\
\hline $\begin{array}{l}2, \\
3\end{array}$ & $\begin{array}{l}\text { Students } \\
2\end{array}$ & 80 & 79 & 78 & 77 & 78,5 \\
\hline 3 & $\begin{array}{l}\text { Students } \\
3\end{array}$ & 83 & 85 & 82 & 84 & 83,5 \\
\hline 3 & $\begin{array}{l}\text { Students } \\
4\end{array}$ & 85 & 84 & 86 & 85 & 85 \\
\hline 3 & $\begin{array}{l}\text { Students } \\
5\end{array}$ & 81 & 84 & 83 & 80 & 82 \\
\hline 3 & $\begin{array}{l}\text { Students } \\
6\end{array}$ & 79 & 77 & 76 & 78 & 77,5 \\
\hline 4 & $\begin{array}{l}\text { Students } \\
7\end{array}$ & 93 & 91 & 87 & 88 & $\begin{array}{l}89,7 \\
5\end{array}$ \\
\hline 4 & $\begin{array}{l}\text { Students } \\
8\end{array}$ & 96 & 93 & 92 & 94 & $\begin{array}{l}93,7 \\
5\end{array}$ \\
\hline & Total & $\begin{array}{l}67 \\
7\end{array}$ & $\begin{array}{l}67 \\
5\end{array}$ & 663 & $\begin{array}{l}66 \\
4\end{array}$ & $\begin{array}{l}669, \\
75\end{array}$ \\
\hline
\end{tabular}

As displays from the result of test four above, the students abilty in speaking are classified in three categories. Students 1 and 2 are classified in mix categories good and very good category as in student 1 , got 80 score for vocabulary and 82 for pronunciation classified as a very good categories for both speaking aspects with little proplem in arranging vocabulary, using grammar and self-correction when to say words. While in grammar (79) and fluency (78) classified as good categories with repetition and rephrasing sometimes necessary during the talks and conversation

Students 3, 4, 5 and 6 are classified in a very good categories. During the conversation, talks and explaination of the pictures in detail, the students are able to explain the contents, situation and some characters found in the pictures as in student 3 got 83 for vocabulary, 85 for pronunciation, 82 for grammar and 84 for fluency. The student 3 faces little problem in understanding and little error in grammar, vocabulary and pronunciation

Students 7 is classified as a very good and an execellent speaking ability categories in vocabulary (93) and pronunciation (91) with clear in oral talks and elaboartion whole the pictures contents in detail and almost no error in vocabulary and pronunciation. While in grammar (87) and fluency (88) classified as a very good category with limited number of errors of grammar, words, pronunciation and occasional did self-corrections

Students 8 is classified as an execellent speaking ability categories as seen in the result of the test of vocabulary (96), pronunciation (93), grammar (92) 
Vol. 3 No. 2

December 2021

e- ISSN 2685 - 0559

p- ISSN 2684 - 673X

and fluency (94) with an exellent capability to speak in Englishthrough elaboration in detail of the pictures, quite clear oral production, faced little difficulty in understanding, almost no errors of phonology, grammar and words

Table 6. Result describtion for test 1, 2, 3 and 4

\begin{tabular}{llllll}
\hline No & Name & Test 1 & Test & Test & Test 4 \\
$\mathbf{.}$ & & & $\mathbf{2}$ & $\mathbf{3}$ & \\
\hline $\mathbf{1}$ & Ameyria & 73,25 & 77 & 81,7 & 89,75 \\
& & & & 5 & \\
$\mathbf{2}$ & Ardo & 70,75 & 75,2 & 79,2 & 83,5 \\
\hline
\end{tabular}

\begin{tabular}{|c|c|c|c|c|c|}
\hline \multirow{2}{*}{3} & & & 5 & 5 & \\
\hline & $\begin{array}{l}\text { Daniel } \\
\text { Pranata }\end{array}$ & 63,25 & $\begin{array}{l}69,7 \\
5\end{array}$ & 77 & 79,75 \\
\hline 4 & Dini & 75,25 & 77,5 & $\begin{array}{l}81,2 \\
5\end{array}$ & 85 \\
\hline 5 & $\begin{array}{l}\text { Elsa } \\
\text { agustina } \\
\text { siagian }\end{array}$ & 73,75 & $\begin{array}{l}71,2 \\
5\end{array}$ & $\begin{array}{l}79,2 \\
5\end{array}$ & 82 \\
\hline 6 & $\begin{array}{l}\text { Haryanto } \\
\text { chang }\end{array}$ & 62 & 66 & 74 & 78,5 \\
\hline 7 & $\begin{array}{l}\text { Irsan } \\
\text { situmea } \\
\text { ng }\end{array}$ & 59,75 & $\begin{array}{l}65,2 \\
5\end{array}$ & 75 & 77,5 \\
\hline 8 & $\begin{array}{l}\text { Tjhang } \\
\text { thien } \\
\text { liung }\end{array}$ & 74,75 & 78,5 & 83 & 93,75 \\
\hline & Total & $\begin{array}{l}543,7 \\
5\end{array}$ & $\begin{array}{l}580, \\
5\end{array}$ & 630 & $\begin{array}{l}669,7 \\
5\end{array}$ \\
\hline
\end{tabular}

Table 7. Result describtion for pre-test and post-test

\begin{tabular}{lllll}
\hline \multicolumn{1}{c}{ Participants } & \multicolumn{3}{c}{ Pre-test } & \multicolumn{2}{c}{ Post-test } \\
\cline { 2 - 5 } Ameyria & Score & Category & Score & Category \\
Ardo & 73,25 & Good & 89,75 & Very good \\
Daniel Pranata & 70,75 & Fair & 83,5 & Very good \\
Dini & 63,25 & Unsatidfactory & 79,75 & Good \\
\hline Elsa agustina siagian & 75,25 & Good & 85 & Very good \\
Haryanto chang & 73,75 & Good & 82 & Very good \\
\hline Irsan situmeang & 62 & Fair & 78,5 & Fair \\
\hline Tjhang thien liung & 59,75 & Unfair & 77,5 & Fair \\
\hline
\end{tabular}

\section{CONCLUSION}

The students' speaking ability improved. Teaching online using digital pictures can develope motivation of the students. Using different pictures for each meeting. The pictures are described from the general information, give the summary for the pictures, explain the pictures more detail, give ideas about the pictures, do speaculating for each picture. The use of digital photos can develop students' speaking ability. The result can be seen from the first test to final test results of the the 8th students. Student 1st test got 63,25 score, 2nd test got 69,75 score, third test got 77 score and fourth test got 79,75 score. Student two first test got 62 score, second test got 66 score, third test got 74 score and fifth test got 78,5 . Student three first test got 59,75 , second test got 65,25 score, the 3rd test got 75 score and the fifth test got 78,5 score. Student three first test got 59,75 score, second test got 65,25 score, third test got 75 score and fifth test got 77,5 . Student four first test got 73,25 , second test got 77 score, the $3 r d$ test got 81,75 score and the fifth test got 89,75 score. Student five first test got 70,75, second test got 75,25 score, the 3rd test got 79,25 score and the fifth test got 83,5 score. Student six first test got 75,25 , second test got 77,5 score, the 3 rd test got 81,25 score and the fifth test got 85 score. Student seven first test got 73,75 , second test got 71,25 score, the 3 rd test got 79,25 
score and the fifth test got 82 score. Student seven first test got 73,75 , second test got 71,25 score, the 3 rd test got 79,25 score and the fifth test got 82 score. Student eight first test got 74,75 , second test got 78,5 score, the 3rd test got 83 score and the fifth test got 93,75 score.

Student one scores from 59,75 improved to 77,5, first test classified as unsatisfied category and final test is good category. Student two scores from 63,25 improved to 79,75 , first test classified as fair category and final test is good category. Student three scores from 63,25 improved to 79,75 , first test classified as fair category and final test is good category. Student four scores from 73,25 improved to 89,75 , first test classified as good category and final test is very good category. Student five scores from 70,75 improved to 83,5 , first test classified as fair category and final test is very good category. Student six scores from 75,25 improved to 85 , first test classified as good category and final test is very good category. Student seven scores from 73,75 improved to 82 , first test classified as good category and final test is very good category. Student eight scores from 74,75 improved to 93,75 , first test classified as good category and final test is excellent category.

The result of the test for student 1 to the student 8 are improved as the score of student 1 , first test result got 63,25 , second test result got 69,75 , third test result got 77 and forth test result got 79,75 . The final result is classified good category of speaking skill ability. The student 4 has improved the speaking ability using digital photos through online learning, the result of first test is 73,25 , result of second test is 77 , result of third test is 81,25 and result of forth test is 89,75 . The student 4 got a very good result as seen in the final test result. For student 8 , the speaking improved as showed form the table test result, test 1 to test 4 . The test 1 result is 74,75 , test 2 result is 78,5 , test 3 result is 83 and test 4 result is 93,75 . The final score shows that the student 8 has improved the speaking ability as seen in the final score is 93,75

\section{REFERENCES}

Arbain \& Nur, D,R,. (2017). Techniques for Teaching Speaking Skill in Widya Gama Mahakam University, Journal of Linguistic and EnglishTeaching, 2 (1)

Arifin, S. \& Purwanti, N,T,. (2016). teaching speaking by using communication games for junior high school students, Englishteaching journal, 4 (1)

Brown, H. D. (2004). Language Assessment: Principle and Classroom Practices. San Francisco State University, London: Pearson Education, Inc.

Burns, A., \& Heken, J. (1997). Focus on Speaking. Sydney: Macquarie University

Cakrawati, L,M,. (2017). Students' perceptions on the use of online learning platforms in efl classroom, Journal of Englishlanguage teaching and technology, 1 (1) 
Creswell John W. 2009. Research design. School of NebraskaLincoln: Sage

Jones, Cery (2018). Teaching Speaking Online, cited from, https://www.cambridge.org/elt/ blog/2018/01/22/introductionteaching-speaking-online-2/

Kiwana, Lousiana (2017). Cited from, https://www.cambridge.org/elt/ blog/2017/11/21/5-tips-forteaching-speaking/

Kothari C. R., 2004. Research methodology. School of Rajasthan (India) : New age international $(P)$ limited

Mounika, K. \& Thamarana, S., (2018). Teaching Speaking Skills Online: Prospects and Possibilities, Eltai Tirupathi cahpter 6th annual international conference, cited from, https://www.researchgate.net/ publication/323252357_Teachin g_Speaking_Skills_Online_Prosp ects_and_Possibilities/link/5a89 09d2a6fdcc6b1a3f8cb4/downlo ad

Nugraha, H., \& Chairunisa. (2020). Analysis Needed for Preparation of Teaching Materials in English for Medical Personnel in Batam City. IdeBahasa, 2(2), 133-140. https://doi.org/10.37296/ideba hasa.v2i2.46

Pakula, Hein, (2019). Teaching spaeking, Apples Journal of Applied Language Studies, 13 ( 1), 95-111

Situmorang, H, D,. (2015). Pentingnya Kompetisi Bahasa Inggris di Era MEA, cited from, https://www.beritasatu.com/ar chive/320084/pentingnya- kompetisi-bahasa-inggris-di-eramea

Sukrianto, M. (2005). Speaking Activities Implemented by Senior High School Teachers in Classroom. EFL Asian Journal, Retrieved from http://www.asian-efljournal.com/

Tahir, S, Z, B,. \& Hanapi,(2017, p.2 ). Lecturers' methot in teaching speaking at the university of Igra Buru, International journal of linguistics, 7 (2)

Brown, H. Douglas. 2004. Language Assessment: Principles and Classroom Practices.San Fransisco State University 
Vol. 3 No. 2

December 2021 